\title{
PROYEKSI KEBUTUHAN ENERGI LISTRIK KABUPATEN PURBALINGGA TAHUN 2030 MENGGUNAKAN SOFTWARE LEAP
}

\author{
Gagat Dwiyoko $^{1}$, Toto Sukisno ${ }^{2}$, Eko Swi Damarwan ${ }^{3}$ \\ ${ }^{123}$ Jurusan Pendidikan Teknik Elektro Universitas Negeri Yogyakarta \\ Email: gagatdwiyoko48@gmail.com
}

\begin{abstract}
The purpose of this study is to project the electrical energy needs of each customer sector and the peak load in Purbalingga Regency until 2030 using the LEAP software. The projected results are expected to be a reference in the supply of electrical energy in Purbalingga Regency to ensure the availability of electricity in Purbalingga Regency. This method of projecting electrical energy needs is carried out with the Econometry, Trend, and End-Use approaches. The development and manufacturing phases consist of: (1) needs analysis, (2) simulation design, (3) simulation phase, and (4) testing process with two scenarios. The projected electrical energy requirements in this research are tested with two scenarios, namely the Business As Usual scenario and the Policy scenario. The results of the projected electricity needs of Purbalingga Regency in 2030 use the Business As Usual scenario in the household customer sector of 296.015,6 MWh, the business sector 78.311,3 MWh, the public sector 62.219,4 MWh and the industrial sector equal to 209.346,3 MWh with a peak load of 94,6 MW. In the policy scenario, the household sector's electricity needs are 297.541 MWh, the business sector is 43.129,3 MWh, the public sector is 36.756,2 MWh, and the industrial sector is 99.216,6 MWh with a peak load of 69,8 MW. In the Business As Usual scenario, it is necessary to increase the capacity of the transformer by $90 \mathrm{MW}$ or $300 \%$ of the previous capacity, but if the policy scenario applied is to increase the capacity of the transformer by $60 \mathrm{MW}$ or $200 \%$ of the previous capacity. Additional transformer capacity is needed to ensure the availability of electricity in Purbalingga Regency until 2030.
\end{abstract}

Keywords: Projected electrical energy requirements, LEAP software

\begin{abstract}
ABSTRAK
Tujuan dari penelitian ini adalah untuk memproyeksikan kebutuhan energi listrik tiap sektor pelanggan serta beban puncak di Kabupaten Purbalingga hingga tahun 2030 menggunakan software LEAP. Hasil proyeksi diharapkan dapat menjadi acuan dalam penyediaan energi listrik dan guna menjamin ketersediaan energi listrik di Kabupaten Purbalingga. Metode proyeksi kebutuhan energi listrik ini dilakukan dengan pendekatan Ekonometri, Trend, dan End-Use. Tahap- tahap pengembangan dan pembuatan yang terdiri dari: (1) analisis kebutuhan, (2) perancangan simulasi, (3) tahap simulasi, dan (4) proses pengujian dengan dua skenario. Proyeksi kebutuhan energi listrik dalam penelitian ini diuji dengan dua skenario yaitu skenario Business As Usual dan skenario Kebijakan. Hasil proyeksi kebutuhan energi listrik Kabupaten Purbalingga tahun 2030 menggunakan skenario Business As Usual pada sektor pelanggan rumah tangga sebesar 296.015,6 MWh, sektor bisnis 78.311,3 MWh, sektor publik 62.219,4 MWh dan sektor industri sebesar 209.346,3 MWh dengan beban puncak 94,6 MW. Pada skenario kebijakan kebutuhan energi listrik sektor rumah tangga sebesar $297.541 \mathrm{MWh}$, sektor bisnis 43.129,3 MWh, sektor publik 36.756,2 MWh dam sektor industri sebesar 99.216,6 MWh dengan beban puncak 69,8 MW. Pada skenario Business As Usual diperlukan penambahan kapasitas trafo sebesar $90 \mathrm{MW}$ atau 300\% kapasitas sebelumnya namun jika skenario kebijakan yang diterapkan penambahan kapasitas trafo sebesar 60 MW atau 200\% dari kapasitas sebelumnya. Penambahan kapasitas trafo diperlukan guna menjamin ketersediaan energi listrik di Kabupaten Purbalingga hingga tahun 2030.
\end{abstract}

Kata kunci: Proyeksi kebutuhan energi listrik, software LEAP 


\section{PENDAHULUAN}

Ketersediaan energi listrik merupakan aspek yang sangat penting dan bahkan menjadi suatu parameter untuk mendukung keberhasilan pembangunan suatu daerah. Energi listrik yang memadai dan tepat sasaran akan memacu perkembangan pembangunan daerah seperti sektor industri, bisnis, pelayanan publik, dan bahkan kualitas hidup masyarakat. Penggunaan energi listrik secara langsung maupun tidak langsung akan mempengaruhi pertumbuhan ekonomi dan kesejahteraan masyarakat. Penggunaan energi listrik diperkirakan akan selalu meningkat setiap tahunnya. Hal ini dikarenakan oleh semakin berkembangnya kebutuhan masyarakat yang harus dipenuhi. Banyak faktor yang berpengaruh terhadap tingkat kebutuhan tenaga listrik, seperti faktor ekonomi,kependudukan, rencana pembangunan, dan lain-lain (Suhono, 2009:16).

Kabupaten Purbalingga merupakan salah satu daerah yang kebutuhan energi listriknya terus meningkat. Hal itu disebabkan karena di Kabupaten Purbalingga jumlah penduduk serta faktor ekonominya terus meningkat (Rencana Pembangunan Jangka Menengah Daerah (RPJMD) Kab. Purbalingga 2016-2021, 2018: 82). Ditambah lagi dengan banyaknya pembangunan industri-industri yang memerlukan banyak energi listrik. Untuk mengantisipasi kurangnya pemenuhan kebutuhan energi listrik di masa yang akan datang maka perlu adanya proyeksi kebutuhan energi listrik agar penyedia energi listrik dalam hal ini PT. PLN mempunyai acuan untuk menambah kapasitas suplai energi listrik di Kabupaten Purbalingga.

Menurut pedoman penyusunan rencana umum ketenagalistrikan daerah yang diterbitkan oleh Kementrian ESDM (2015), terdapat 4 sektor konsumsi energi dalam pembagian pelanggan yaitu: sektor rumah tangga, sektor bisnis, sektor publik, dan sektor industri. Sektor tersebut yang akan dilakukan proyeksi kebutuhan energi listriknya.
Terdapat berbagai model pendekatan untuk menyusun prakiraan kebutuhan tenaga listrik yang tersedia antara lain: pendekatan ekonometrik, proses, time series, end-use, trend maupun gabungan dari berbagai model pendekatan perencanaan (Prawaningtyas, 2009). Metode yang digunakan sebagai pendekatan untuk proyeksi kebutuhan energi listrik pada penelitian ini adalah metode pendekatan ekonometri, trend, dan end-use. Perbedaan utama dari ketiga metode tersebut adalah pada jenis data yang dimasukkan (data input). Pada model ekonometri, data yang digunakan sebagai data masukan seperti pendapatan daerah, pendapatan per kapita dan data lain yang bersifat ekonomi, kemudian dihubungkan dengan kebutuhan energi (Herbst, A., Toro, F., Reitze, F., \& Jochem, E., 2012).

Pendekatan trend dilakukan dengan melakukan proyeksi berdasarkan data historis di masa lalu (Suhono, 2009:17). Data tersebut kemudian diekstrapolasikan berdasarkan kecenderungan yang terjadi. Keunggulannya adalah data yang diperlukan bersifat sederhana. Namun, ada juga kelemahannya terutama karena tidak dapat menggambarkan perubahan struktural yang terjadi dari masing-masing variabel yang berpengaruh baik untuk faktor teknologi maupun ekonomi. Selain itu, ada kecenderungan bahwa kejadian di masa lalu tidak secara tegas akan menggambarkan kondisi pada masa yang akan datang.

Metode pendekatan end-use juga dikenal sebagai pendekatan engineering model. Pendekatan ini akan lebih detail walaupun secara perhitungan menggunakan fungsi yang lebih sederhana (Djohar, A., \& Musaruddin, M, 2017). Pertimbangan teknologi yang digunakan dalam proses aliran energi juga menjadi variabel perhitungan. Pendekatan ini sangat cocok untuk keperluan proyeksi efisiensi energi karena dimungkinkan untuk secara eksplisit mempertimbangkan perubahan teknologi dan tingkat pelayanan. Permintaan energi dari masing-masing kegiatan merupakan produk dari dua faktor, yaitu tingkat aktivitas (layanan 
energi) dan intensitas energi (penggunaan energi per unit layanan energi). Selain itu, permintaan total maupun permintaan energi sektoral dipengaruhi oleh rincian kegiatan yang berbeda yang membentuk komposisi, atau struktur permintaan energi.

Proses proyeksi kebutuhan energi listrik memerlukan perangkat lunak. Perangkat tersebut digunakan untuk mengolah serta mendapatkan hasil proyeksi kebutuhan energi listrik. Salah satu perangkat lunak yang dapat digunakan untuk melakukan proyeksi kebutuhan energi listrik adalah perangkat lunak LEAP (Long Range Energy Alternative Planning. LEAP terdiri dari empat modul utama yaitu Modul Variabel Penggerak (Driver Variable) yang dalam versi baru disebut juga Key Assumptions, Modul Permintaan (Demand), Modul Transformasi (Transformation) dan Modul Sumber Daya Energi (Resources) (Winarno, O. T, 2006). Gambar software LEAP ditampilkan pada Gambar 1.

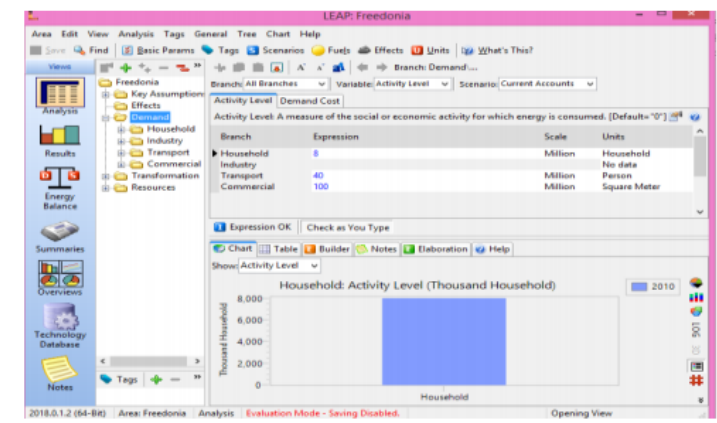

Gambar 1. Tampilan Software LEAP

Terkait prakiraan energi listrik yang menggunakan LEAP terdapat beberapa penelitian yang relevan. Penelitian terkait proyeksi kebutuhan dan penyediaan energi listrik di Jawa Tengah yang menyajikan hasil prakiraan berupa neraca komuditas listrik, konsumsi energi, dan produksi energi listrik (Hermawan, H., \& Karnoto, K, 2011). Penelitian lain berupa analisis kebutuhan dan penyediaan energi listrik di Kabupaten Konawe Kepulauan Tahun 2017-2036 dengan menggunakan perangkat lunak LEAP menyajikan potensi energi yang dapat dimanfaatkan untuk memenuhi kebutuhan energi listrik Kabupaten Konawe Kepulauan diantaranya yaitu potensi energi air, potensi energi tenaga surya (Djohar, A., \& Musaruddin, M, 2017). LEAP mampu merangkai skenario untuk berapa konsumsi energi listrik yang dipakai, dikonversi, dan diproduksi dalam suatu sistem energi dengan berbagai alternatif. Asumsi yang dapat digunakan sebagai alternatif LEAP meliputi kependudukan, pembangunan ekonomi, teknologi, harga, dan sebagainya. Oleh karena itu penelitian ini membahas terkait proyeksi kebutuhan energi listrik meliputi: pertumbuhan konsumsi energi listrik, persentase kenaikan beban puncak, dan penambahan kapasitas trafo di Kabupaten Purbalingga dari tahun 2015 sampai 2030 menggunakan software LEAP.

\section{METODE}

Metode proyeksi kebutuhan energi listrik dilakukan dengan pendekatan Ekonometri, Trend, dan End-Use dengan skenario Business As Usual dan kebijakan. Metode penelitian ini terdiri dari empat langkah yaitu analisis kebutuhan, konsep perancangan, tahap simulasi, dan perencanaan pengujian.

Tahap Analisis Kebutuhan, proyeksi kebutuhan energi listrik di masa yang akan datang diperlukan data-data serta peralatan yang mendukung proses proyeksi kebutuhan energi listrik. Data yan diperlukan meliputi: daftar peralatan, bahan, jumlah penduduk, data Produk Domestik Regional Bruto (PDRB) Kabupaten Purbalingga, pelanggan energi listrik, konsumsi energi listrik, intensistas energi lisrik, faktor kapasitas pelanggan, elastisistas energi, dan data asumsi.

Tahapan Perancangan merupakan tahapan untuk merancang kebutuhan proses simulasi di perangkat lunak LEAP (Winarno, O. T, 2006). Pada tahap perencanaan Tree Modul Penggerak (Key Assumption), modul variable Penggerak (Key Assumption) berisi parameter dasar yang akan mempengaruhi modul permintaan. Parameter modul penggerak berupa 
rancangan tree modul variabel penggerak secara rinci terdapat pada Tabel 1 berikut.

Tabel 1. Rancangan Tree Modul Variabel Penggerak

\begin{tabular}{lll}
\hline Kategori & Branch & \multicolumn{1}{c}{ Units } \\
\hline Pelanggan & Jumlah Penduduk & Jiwa \\
& Jumlah Orang Per Rumah Tangga & Jumlah Orang/Rumah Tangga \\
& Jumlah Rumah Tangga & Rumah Tangga \\
& Rasio Elektrifikasi & Persen \\
& Pelanggan Rumah Tangga & Pelanggan \\
& Pelanggan Publik & Pelanggan \\
& Pelanggan Bisnis & Pelanggan \\
& Pelanggan Industri & Pelanggan \\
& a_Losses & Persen \\
\hline Intensitas & a_loadfactor & Persen \\
Energi & Intensitas Energi Rumah Tangga & MWh/Pelanggan \\
& Intensitas Energi Publik & MWh/Pelanggan \\
& Intensitas Energi Industri & MWh/Pelanggan \\
& & MWh/Pelanggan \\
\hline
\end{tabular}

Perencanaan Tree Modul permintaan (demand) yaitu merupakan modul yang berfungsi untuk menghitung permintaan energi, penelitian ini menghitung permintaan energi listrik berdasarkan parameter yang ada pada modul variabel penggerak (Key Assumptions).

Pada tahap Perancangan Skenario Proyeksi, simulasi yang digunakan berupa dua skenario berdasarkan pendekatan Ekonometri, Trend dan End-Use yaitu; (1) Skenario Business As Usual dimana pertumbuhan kebutuhan energi listrik akan terus tumbuh tanpa adanya kendali dari faktor ekonomi maupun kebijakankebijakan yang lainnya. Selanjutnya dalam penelitian ini skenario Business As Usual akan disebut dengan skenario satu, (2) Skenario Kebijakan dimana proyeksi energi kebutuhan energi listrik akan dihitung dari tahun 2016 hingga 2030. Perhitungan menggunakan dua skenario pertumbuhan permintaan energi yaitu skenario pertama untuk tahun 2016 - 2021 yang dalam penghitungan pertumbuhannya didasarkan pada data historis tahun sebelumnya tanpa adanya pengaruh faktor pertumbuhan ekonomi ataupun kebijakan lainnya. Hal ini diasumsikan karena dalam RPJMD 2016 - 2021 tidak disinggung masalah kebutuhan energi listrik sedangkan pada skenario kedua untuk tahun 2022 - 2030 perhitungan pertumbuhannya dipengaruhi oleh faktor pertumbuhan ekonomi. Diasumsikan dengan disusunnya RPJMD yang baru pertumbuhan kebutuhan energi listrik dapat dikontrol dan sebanding dengan pertumbuhan ekonomi. Selain karena faktor ekonomi, dalam skenario ini pertumbuhan penduduk juga akan dikendalikan sesuai kebijakan pemerintah. Selanjutnya dalam penelitian ini skenario kebijakan akan disebut dengan skenario kedua.

Setelah konsep rancangan telah dibuat kemudian dilanjutkan dengan Tahap Simulasi. Tujuan tahap simulasi adalah mengimplementasikan tahapan perancangan ke dalam software LEAP. Tahap simulasi meliputi; (1) Pengaturan Parameter Dasar dimana pengaturan parameter dasar berupa pengaturan tahun dasar simulasi, tahun akhir simulasi, serta tahun awal skenario, (2) Pembuatan Tree Key Assumptions pada software LEAP dimana Nama, Data, dan Units diisi berdasarkan rancangan yang telah dibuat, (3) Pembuatan Tree Demand pada software LEAP, Nama serta susunannya diisi berdasarkan rancangan yang telah dibuat, (3) Pembuatan Skenario untuk mendapatkan hasil simulasi yang diinginkan berdasarkan skenario yang dirancang, (4) 
Pembuatan Ekspresi Key Assumptions dimana Ekspresi adalah perintah yang digunakan pada software LEAP yang berfungsi untuk mengolah data-data sedemikan rupa sesuai kebutuhan, ekspresi yang digunakan yaitu Growth dan Interpm, (5) Pembuatan Ekspresi pada Tree Demand, permintaan energi dihitung berdasarkan dua variabel yaitu jumlah pelanggan dan intensitas energi yang ada pada Key Assumptions.

Tahap perencanaan pengujian bertujuaan agar proses pengujian memiliki keluaran sesuai kebutuhan dalam penelitian ini. Dalam proses pengujian langkah - langkah yang dilakukan adalah sebagai berikut; (1) Memastikan seluruh data yang dibutuhkan telah tersedia, (2) Memastikan pengaturan parameter dasar telah setting dengan benar dan sesuai kebutuhan, (3) Memastikan data-data yang dimasukan ke dalam software LEAP telah sesuai, (4) Memastikan ekspresi/formula yang dimasukan ke dalam software LEAP benar dan sesuai kebutuhan, (5) Melakukan simulasi proyeksi kebutuhan energi listrik pada software LEAP pada masing-masing skenario yang telah dibuat.

\section{HASIL DAN PEMBAHASAN}

Data hasil proses proyeksi menggunakan software LEAP menghasilkan data hasil proyeksi asumsi pertumbuhan PDRB dimana dalam memproyeksikan kebutuhan energi listrik di masa yang akan datang diperlukan data asumsi pertumbuhan PDRB pada masing masing sektor pelanggan. Data pertumbuhan PDRB masing-masing sektor pelanggan ditunjukkan pada Tabel 2.

Hasil proyeksi pertumbuhan PDRB pada Tabel 2 merupakan proyeksi yang diasumsikan bahwa pertumbuhan PDRB dari tahun dasar 2015 pada masing-masing sektor sebesar 6,5\% pada sektor rumah tangga, 6,9\% sektor bisnis, $5,9 \%$ sektor publik dan $5,1 \%$ pada sektor industri akan mengalami peningkatan pertumbuhan PDRB mencapai $7,5 \%$ di tahun 2030 pada masing-masing sektor pelanggan.
Pertumbuhan PDRB mengacu pada pada jurnal Kajian Perencanaan Kebutuhan dan Pemenuhan Energi Listrik di Kota Manado (Rajagukguk, A. S., Pakiding, M., \& Rumbayan, M, 2015). Berdasarkan Tabel 2 ditunjukkan bahwa sektor bisnis dan rumah tangga memiliki proyeksi asumsi pertumbuhan PDRB paling besar.

Tabel 2. Hasil Proyeksi Asumsi Pertumbuhan PDRB

\begin{tabular}{rrrrr}
\hline & \multicolumn{4}{c}{ Empat Sektor Pelanggan } \\
\cline { 2 - 5 } Tahun & $\begin{array}{c}\text { Rumah } \\
\text { Tangga } \\
(\boldsymbol{\%})\end{array}$ & $\begin{array}{c}\text { Bisnis } \\
(\%)\end{array}$ & $\begin{array}{c}\text { Publik } \\
(\%)\end{array}$ & $\begin{array}{c}\text { Industri } \\
(\%)\end{array}$ \\
\hline 2015 & 6,5 & 6,9 & 5,9 & 5,1 \\
2016 & 6,6 & 6,9 & 6 & 5,3 \\
2017 & 6,6 & 7 & 6,1 & 5,4 \\
2018 & 6,7 & 7 & 6,2 & 5,6 \\
2019 & 6,8 & 7,1 & 6,3 & 5,7 \\
2020 & 6,9 & 7,1 & 6,4 & 5,9 \\
2021 & 7 & 7,1 & 6,5 & 6,1 \\
2022 & 7 & 7,2 & 6,6 & 6,2 \\
2023 & 7,1 & 7,2 & 6,8 & 6,4 \\
2024 & 7,1 & 7,3 & 6,9 & 6,5 \\
2025 & 7,2 & 7,3 & 7 & 6,7 \\
2026 & 7,2 & 7,3 & 7,1 & 6,9 \\
2027 & 7,3 & 7,4 & 7,2 & 7 \\
2028 & 7,4 & 7,4 & 7,3 & 7,2 \\
2029 & 7,4 & 7,5 & 7,4 & 7,3 \\
2030 & 7,5 & 7,5 & 7,5 & 7,5 \\
\hline
\end{tabular}

Hasil proyeksi rasio elektrifikasi menentukan banyaknya jumlah pelanggan pada sektor rumah tangga. Nilai rasio elektrifikasi pada tahun dasar didapatkan dari presentase hasil pembagian jumlah pelanggan sektor rumah tangga dengan jumlah rumah tangga. Semakin besar nilai rasio elektrifikasi maka jumlah pelanggan sektor rumah tangga akan semakin bertambah. Hasil proyeksi rasio elektrifikasi ditunjukkan pada Tabel 3.

Berdasarkan Tabel 3 ditunjukkan pada tahun 2015 rasio elektrifikasi di Kabupaten Purbalingga adalah $87,2 \%$ dari total rumah tangga sebanyak 225116 (Badan Pusat Statistik (BPS) Kab. Purbalingga, 2015). Rasio elektrifikasi di Kabupaten Purbalingga diharapkan mencapai angka 100\% tahun 2030. Artinya seluruh rumah tangga menikmati energi listrik. Hasil proyeksi diperoleh dari software LEAP menggunakan fungsi interp. 
Tabel 3. Hasil Proyeksi Rasio Elektrifikasi

\begin{tabular}{cccc}
\hline \multicolumn{3}{c}{ Hasil Proyeksi Rasio Elektrifikasi } \\
\hline Tahun & $\begin{array}{c}\text { Rasio } \\
\text { Elektrifikasi } \\
(\%)\end{array}$ & Tahun & $\begin{array}{c}\text { Rasio } \\
\text { Elektrifikasi } \\
(\%)\end{array}$ \\
\hline 2015 & 87,2 & 2023 & 94,0 \\
2016 & 88,1 & 2024 & 94 \\
2017 & 88,9 & 2025 & 94,9 \\
2018 & 89,8 & 2026 & 96,6 \\
2019 & 90,6 & 2027 & 97,4 \\
2020 & 91,5 & 2028 & 98,3 \\
2021 & 92,3 & 2029 & 99,1 \\
2022 & 93,2 & 2030 & 100 \\
\hline
\end{tabular}

Hasil proyeksi elastisitas energi masingmasing sektor pelanggan digunakan sebagai faktor perhitungan konsumsi energi listrik. Hasil proyeksi elastisitas energi ditunjukkan pada Tabel 4.

Tabel 4. Hasil Proyeksi Elastisitas Energi

\begin{tabular}{ccccc}
\hline \multirow{2}{*}{ Tahun } & \multicolumn{4}{c}{ Sektor Pelanggan } \\
\cline { 2 - 5 } & $\begin{array}{c}\text { Rumah } \\
\text { Tangga }\end{array}$ & Bisnis & Publik & Industri \\
\hline 2015 & 0,9 & 1,3 & 1,4 & 2,1 \\
2016 & 0,9 & 1,3 & 1,4 & 2,1 \\
2017 & 0,9 & 1,3 & 1,3 & 2,0 \\
2018 & 0,9 & 1,2 & 1,3 & 1,9 \\
2019 & 0,9 & 1,2 & 1,3 & 1,8 \\
2020 & 0,9 & 1,2 & 1,3 & 1,8 \\
2021 & 0,9 & 1,2 & 1,2 & 1,7 \\
2022 & 0,9 & 1,2 & 1,2 & 1,6 \\
2023 & 0,9 & 1,1 & 1,2 & 1,5 \\
2024 & 0,9 & 1,1 & 1,2 & 1,5 \\
2025 & 0,9 & 1,1 & 1,1 & 1,4 \\
2026 & 0,9 & 1,1 & 1,1 & 1,3 \\
2027 & 0,9 & 1,1 & 1,1 & 1,2 \\
2028 & 0,9 & 1,0 & 1,1 & 1,2 \\
2029 & 0,9 & 1,0 & 1,0 & 1,1 \\
2030 & 0,9 & 1,0 & 1,0 & 1,0 \\
\hline
\end{tabular}

Berdasarkan Tabel 4 ditunjukkan bahwa elastisitas energi dari tahun dasar 2015 pada masing-masing sektor sebesar 0,9 pada sektor rumah tangga, 1,3 sektor bisnis, 1,4 sektor publik, dan 2,1 pada sektor industri akan dibatasi maksimal bernilai 1 pada tahun $2030 \mathrm{di}$ setiap sektor. Hal ini sesuai dengan hasil penelitian Insani, D. S., Badriana, B., \& Daud, M. (2019: 40) yang menjelaskan elastisitias energi akan menurun terus hingga mencapai 0,61 pada tahun 2026 di Kabupaten Bireuen.

Hasil proyeksi asumsi losses pada penelitian ini digunakan untuk menghitung total konsumsi energi. Hasil proyeksi losses ditunjukkan Tabel 5.

Tabel 5. Hasil Proyeksi Asumsi Losses

\begin{tabular}{ccrc}
\hline Tahun & Losses (\%) & Tahun & Losses $(\%)$ \\
\hline 2015 & 10 & 2023 & 7,3 \\
2016 & 9,7 & 2024 & 7,0 \\
2017 & 9,3 & 2025 & 6,7 \\
2018 & 9,0 & 2026 & 6,3 \\
2019 & 8,7 & 2027 & 6,0 \\
2020 & 8,3 & 2028 & 5,7 \\
2021 & 8,0 & 2029 & 5,3 \\
2022 & 7,7 & 2030 & 5,0 \\
\hline
\end{tabular}

Berdasarkan Tabel 5 ditunjukkan bahwa hasil proyeksi asumsi loses tahun 2015 sebesar 10\% turun menjadi 5,0\% pada tahun 2030. Hasil proyeksi losses diasumsikan berdasarkan buku ketahanan energi nasional dimana losses diharapkan di bawah 10\% (Dewan Energi Nasional, 2015). Pada penelitian ini losses diasumsikan akan terus berkurang hingga 5\% pada tahun 2030.

Hasil proyeksi asumsi load factor digunakan dalam perhitungan beban puncak. Hasil proyeksi asumsi load factor ditunjukkan pada Tabel 6.

Tabel 6. Hasil Proyeksi Asumsi Load Factor

\begin{tabular}{cccc}
\hline Tahun & $\begin{array}{c}\text { Load } \\
\text { Factor } \\
(\%)\end{array}$ & Tahun & $\begin{array}{c}\text { Load } \\
\text { Factor } \\
(\%)\end{array}$ \\
\hline 2015 & 79,0 & 2023 & 80,6 \\
2016 & 79,2 & 2024 & 80,8 \\
2017 & 79,4 & 2025 & 81,0 \\
2018 & 79,6 & 2026 & 81,2 \\
2019 & 79,8 & 2027 & 81,4 \\
2020 & 80,0 & 2028 & 81,6 \\
2021 & 80,2 & 2029 & 81,8 \\
2022 & 80,4 & 2030 & 82,0 \\
\hline
\end{tabular}

Berdasarkan Tabel 6 ditunjukkan bahwa hasil proyeksi asumsi load factor tahun 2015 sebesar 79,0\% naik menjadi 82,0\% pada tahun 2030 . Hasil proyeksi load factor pada penilitian ini didasarkan pada Rencana Penyediaan Umum Tenaga Listrik (RUPTL) PT. PLN tahun 2016 2025 dimana pada tahun 2016 load factor di Provinsi Jawa Tengah sebesar 79,3\% dan tahun 
2025 sebesar 89,7\%. Dalam penelitian ini load factor diasumsikan sebesar $79,0 \%$ dan akan meningkat hingga 82,0\% di tahun 2030 .
Hasil proyeksi pelanggan ditunjukkan pada Tabel 7 dan Tabel 8 merupakan faktor yang berpengaruh terhadap besar kecilnya konsumsi energi listrik dari masing-masing sektor.

Tabel 7. Hasil Proyeksi Pelanggan Skenario Satu

\begin{tabular}{cccccc}
\hline \multirow{2}{*}{ Tahun } & \multicolumn{5}{c}{ Pelanggan } \\
\cline { 2 - 6 } & Rumah Tangga & Bisnis & Publik & Industri & Total \\
\hline 2015 & 196.378 & 6.375 & 3.574 & 126 & 206.453 \\
2016 & 200.224 & 6.783 & 3.886 & 133 & 211.026 \\
2017 & 204.206 & 7.217 & 4.225 & 141 & 215.789 \\
2018 & 208.248 & 7.679 & 4.594 & 149 & 220.670 \\
2019 & 212.351 & 8.170 & 4.995 & 157 & 225.673 \\
2020 & 216.516 & 8.693 & 5.431 & 167 & 230.807 \\
2021 & 220.743 & 9.249 & 5.905 & 176 & 236.073 \\
2022 & 225.034 & 9.841 & 6.420 & 186 & 241.481 \\
2023 & 229.388 & 10.471 & 6.981 & 197 & 247.037 \\
2024 & 233.808 & 11.141 & 7.591 & 209 & 252.749 \\
2025 & 238.294 & 11.854 & 8.253 & 221 & 258.622 \\
2026 & 242.846 & 12.613 & 8.974 & 234 & 264.667 \\
2027 & 247.466 & 13.420 & 9.757 & 247 & 270.890 \\
2028 & 252.154 & 14.279 & 10.609 & 262 & 277.304 \\
2029 & 256.912 & 15.193 & 11.535 & 277 & 283.917 \\
2030 & 261.741 & 16.166 & 12.542 & 293 & 290.742 \\
\hline
\end{tabular}

Tabel 8. Hasil Proyeksi Pelanggan Skenario Kedua

\begin{tabular}{llllll}
\hline & \multicolumn{5}{c}{ Pelanggan } \\
\cline { 2 - 6 } Tahun & $\begin{array}{l}\text { Rumah } \\
\text { Tangga }\end{array}$ & Bisnis & Publik & Industri & Total \\
\hline 2015 & 196.378 & 6.375 & 3.574 & 126 & 206.453 \\
2016 & 200.224 & 6.783 & 3.886 & 133 & 211.026 \\
2017 & 204.206 & 7.217 & 4.225 & 141 & 215.789 \\
2018 & 208.248 & 7.679 & 4.594 & 149 & 220.670 \\
2019 & 212.351 & 8.170 & 4.995 & 157 & 225.673 \\
2020 & 216.516 & 8.693 & 5.431 & 167 & 230.807 \\
2021 & 220.743 & 9.249 & 5.905 & 176 & 236.073 \\
2022 & 224.009 & 9.342 & 5.964 & 178 & 239.493 \\
2023 & 227.304 & 9.435 & 6.024 & 180 & 242.943 \\
2024 & 230.628 & 9.530 & 6.084 & 182 & 246.424 \\
2025 & 233.587 & 9.625 & 6.145 & 183 & 249.540 \\
2026 & 236.564 & 9.721 & 6.206 & 185 & 252.676 \\
2027 & 239.561 & 9.819 & 6.269 & 187 & 255.836 \\
2028 & 242.578 & 9.917 & 6.331 & 189 & 259.015 \\
2029 & 245.613 & 10.016 & 6.395 & 191 & 262.215 \\
2030 & 248.669 & 10.117 & 6.459 & 193 & 265.438 \\
\hline
\end{tabular}

Hasil proyeksi pelanggan di Kabupaten Purbalingga menunjukkan adanya peningkatan 
dari 2015 hingga tahun 2030 dengan total 206.453 pelanggan menjadi 290.742 pada skenario satu dan menjadi 265.438 pada skenario kedua. Peningkatan jumlah pelanggan dalam kurun waktu 15 tahun adalah $40 \%$ pada skenario satu dan $28,5 \%$ pada skenario kedua.

Perbedaan pertumbuhan pelanggan sektor rumah tangga pada skenario satu dan dua disebabkan oleh faktor pertumbuhan penduduk serta pertumbuhan rumah tangga. Pada skenario satu pertumbuhan penduduk dan rumah tangga konstan dengan pertumbuhan penduduk sebesar $1,04 \%$ dan pertumbuhan rumah tangga sebesar $1,01 \%$. Sedangkan pada skenario kedua pertumbuhan penduduk mengalami penurunan, pada tahun 2022 pertumbuhan penduduk sebesar $0,58 \%$ dan pada tahun 2025 sebesar $0,41 \%$ begitu juga dengan pertumbuhkan rumah tangga menurun menjadi $0,55 \%$ pada tahun 2022 dan $0,38 \%$ di tahun 2025. Pertumbuhan penduduk dan rumah tangga pada skenario dua didasarkan pada proyeksi perumbuhan penduduk Indonesia Provinsi Jawa Tengah.

Pertumbuhan pelanggan sektor bisnis dalam kurun waktu 15 tahun sebesar $210 \%$ pada skenario satu dan $80 \%$ pada skenario kedua. Selisih pertumbuhan skenario satu dengan skenario dua sebesar $130 \%$. Perbedaan pertumbuhan skenario satu dengan dua di pengaruhi faktor pertumbuhan ekonomi dan faktor kapasitas pelanggan yang di gunakan dalam skenario kedua sedangkan skenario satu hanya berdasarkan pertumbuhan tahun sebelumnya.

Pertumbuhan sektor pelanggan publik dalam kurun waktu 15 tahun sebesar $153 \%$ pada sekenario satu dan $58,69 \%$ pada skenario kedua. Selisih pertumbuhan skenario satu dengan skenario dua sebesar $94.31 \%$. Perbedaan pertumbuhan skenario satu dengan dua di pengaruhi faktor pertumbuhan ekonomi dan faktor kapasitas pelanggan yang di gunakan dalam skenario kedua sedangkan skenario satu hanya berdasarkan pertumbuhan tahun sebelumnya.
Pertumbuhan sektor pelanggan industri dalam kurun waktu 15 tahun sebesar $132 \%$ pada skenario satu dan $53 \%$ pada skenario kedua. Selisih pertumbuhan skenario satu dengan skenario dua sebesar 79\%. Perbedaan pertumbuhan skenario satu dengan dua di pengaruhi faktor pertumbuhan ekonomi dan faktor kapasitas pelanggan yang di gunakan dalam skenario kedua sedangkan skenario satu hanya berdasarkan pertumbuhan tahun sebelumnya.

Hasil proyeksi intensitas energi merupakan faktor yang mempengaruhi besarnya konsumsi energi listrik baik pada skenario satu maupun skenario kedua. Hasil proyeksi intensitas energi masing-masing skenario ditunjukkan pada Tabel 9 dan 10 .

Tabel 9. Hasil Proyeksi Intensitas Energi Skenario Satu

\begin{tabular}{ccccc}
\hline \multirow{2}{*}{ Tahun } & \multicolumn{4}{c}{ Intensitas Energi } \\
\cline { 2 - 5 } & $\begin{array}{c}\text { Rumah } \\
\text { Tangga }\end{array}$ & Bisnis & Publik & Industri \\
\hline 2015 & 1,1 & 6,0 & 3,0 & 355,0 \\
2016 & 1,1 & 6,0 & 3,1 & 371,9 \\
2017 & 1,1 & 6,0 & 3,1 & 389,6 \\
2018 & 1,1 & 6,1 & 3,2 & 408,2 \\
2019 & 1,1 & 6,1 & 3,2 & 427,6 \\
2020 & 1,1 & 6,1 & 3,3 & 448,0 \\
2021 & 1,1 & 6,1 & 3,3 & 469,3 \\
2022 & 1,1 & 6,1 & 3,4 & 491,6 \\
2023 & 1,1 & 6,1 & 3,4 & 515,0 \\
2024 & 1,1 & 6,2 & 3,5 & 539,6 \\
2025 & 1,1 & 6,2 & 3,5 & 565,2 \\
2026 & 1,1 & 6,2 & 3,6 & 592,1 \\
2027 & 1,1 & 6,2 & 3,7 & 620,3 \\
2028 & 1,1 & 6,2 & 3,7 & 649,9 \\
2029 & 1,1 & 6,2 & 3,8 & 680,8 \\
2030 & 1,1 & 6,2 & 3,8 & 713,2 \\
\hline
\end{tabular}

Hasil proyeksi konsumsi energi listrik di Kabupaten Purbalingga menunjukan adanya peningkatan dari tahun 2015 hingga 2030 dengan total konsumsi energi 295.548,7 MWh menjadi 645.892,6 MWh pada skenario satu dan menjadi 476.643,1 MWh pada skenario kedua. Peningkatan konsumsi energi dalam kurun waktu 15 tahun adalah $118 \%$ pada skenario satu 
dan $61,3 \%$ pada skenario kedua. Hal ini sejalan dengan hasil penelitian dari Asri, R (2017: 46) yang menjelaskan bahwa proyeksi konsumsi energi persektor di Sulawesi Selatan selalu naik setiap tahunnya. Berdasarkan hasil proyeksi diketahui perbedaan pertumbuhan konsumsi energi listrik antara skenario satu dengan dua sebesar $56,7 \%$.

Tabel 10. Hasil Proyeksi Intensitas Energi Pelanggan Skenario Kedua

\begin{tabular}{ccccc}
\hline \multirow{2}{*}{ Tahun } & \multicolumn{4}{c}{ Intensitas Energi } \\
\cline { 2 - 5 } & $\begin{array}{c}\text { Rumah } \\
\text { Tangga }\end{array}$ & Bisnis & Publik & Industri \\
\hline 2015 & 1,1 & 6,0 & 3,0 & 355,0 \\
2016 & 1,1 & 6,0 & 3,1 & 371,9 \\
2017 & 1,1 & 6,0 & 3,1 & 389,6 \\
2018 & 1,1 & 6,1 & 3,2 & 408,2 \\
2019 & 1,1 & 6,1 & 3,2 & 427,6 \\
2020 & 1,1 & 6,1 & 3,3 & 448,0 \\
2021 & 1,1 & 6,1 & 3,3 & 469,3 \\
2022 & 1,1 & 6,2 & 3,4 & 474,0 \\
2023 & 1,1 & 6,2 & 3,4 & 478,7 \\
2024 & 1,1 & 6,3 & 3,4 & 483,5 \\
2025 & 1,1 & 6,4 & 3,5 & 488,4 \\
2026 & 1,1 & 6,4 & 3,5 & 493,3 \\
2027 & 1,2 & 6,5 & 3,5 & 498,2 \\
2028 & 1,2 & 6,5 & 3,6 & 503,2 \\
2029 & 1,2 & 6,6 & 3,6 & 508,2 \\
2030 & 1,2 & 6,7 & 3,6 & 513,3 \\
\hline
\end{tabular}

Proporsi konsumsi energi listrik tahun 2030 di Kabupaten Purbalingga pada skenario satu ditunjukkan pada Gambar 2 dan proporsi konsumsi energi listrik pada skenario dua ditunjukkan pada Gambar 3.

\section{Proporsi Konsumsi Energi Listrik}

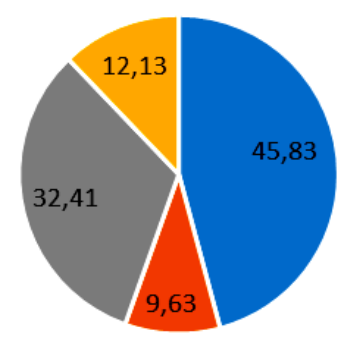

- Rumah Tangga - Bisnis $\mid$ Publik = Industri

Gambar 2. Proporsi Konsumsi Energi Listrik Skenario Satu

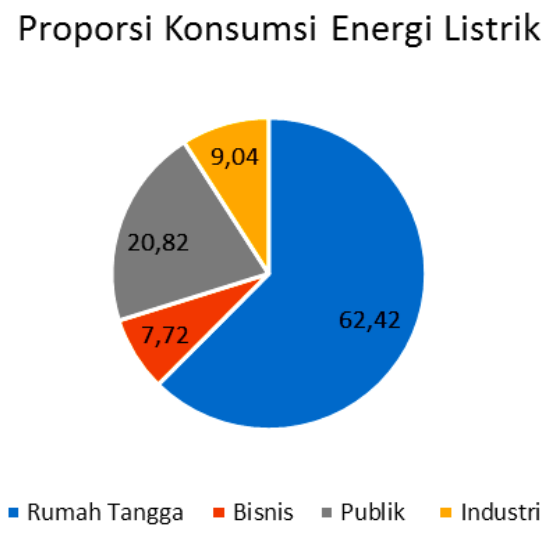

Gambar 3. Proporsi Konsumsi Energi Listrik Skenario Dua

Total konsumsi energi listrik adalah hasil dari konsumsi energi listrik ditambah dengan losses. Total konsumsi energi mengalami peningkatan dari tahun ke tahun karena dipengaruhi oleh konsumsi energi yang terus meningkat. Meskipun losses dari tahun ke tahun semakin berkurang tetapi tidak membuat total konsumsi energi menurun. Presentase peningkatan total konsumsi energi listrik dari tahun 2015 hingga tahun 2030 sebesar 107\% pada skenario satu dan $52,7 \%$ pada skenario dua. Selesih pertumbuhan total konsumsi energi listrik antara skenario satu dengan dua sebesar 54,3\%. Hal ini sejalan dengan hasil penelitian Kassa, D., Tuegeh, M., \& Pakiding, M (2014: 53) yang menjelaskan bahwa berdasarkan hasil proyeksi kebutuhan energi listrik Sulut (Sulawesi Utara) sampai 2020 mengalami 
kenaikan, sehingga diperlukan rencana penambahan kapasitas pembangkit.

Pertumbuhan konsumsi energi listrik dari tahun 2015 hingga tahun 2030 pada sektor pelanggan rumah tangga dari total konsumsi energi 210.124,5 MWh menjadi 296.015,6 MWh naik 40,8\% pada skenario satu sedangkan pada skenario kedua konsumsi energi menjadi 297.541 MWh naik 41,6\%.

Pada sektor pelanggan bisnis total konsumsi dari 21.494 MWh menjadi 78.311,3 MWH naik 269\% pada skenario satu sedangkan pada skenario kedua konsumsi energi menjadi 43.129,3 MWh naik 100\%. Ditinjau pada sektor pelanggan publik dari total konsumsi energi 19.195,1 MWh menjadi 62.219,4 MWh naik 224\% sedangkan pada skenario kedua konsumsi energi menjadi 36.756,2 MWh naik 91\%. Ditinjau sektor pelanggan industri, dari total konsumsi energi 44.735 MWh menjadi 209.346,3 MWh naik 367\% sedangkan pada skenario kedua konsumsi energi menjadi 99.216,6 MWh naik $122 \%$.

Hasil proyeksi beban puncak merupakan hasil dari perhitungan total konsumsi energi dengan load factor. Hasil proyeksi beban puncak ditunjukkan pada Tabel 11 dan Tabel 12.

Tabel 11. Hasil Proyeksi Beban Puncak Skenario Satu

\begin{tabular}{cccc}
\hline Tahun & $\begin{array}{c}\text { Beban } \\
\text { Puncak(MW) }\end{array}$ & Tahun & $\begin{array}{c}\text { Beban } \\
\text { Puncak(MW) }\end{array}$ \\
\hline 2015 & 47,5 & 2023 & 66,3 \\
2016 & 49,3 & 2024 & 69,4 \\
2017 & 51,2 & 2025 & 72,9 \\
2018 & 53,3 & 2026 & 76,6 \\
2019 & 55,6 & 2027 & 80,6 \\
2020 & 58,0 & 2028 & 84,9 \\
2021 & 60,5 & 2029 & 89,6 \\
2022 & 63,3 & 2030 & 94,6 \\
\hline
\end{tabular}

Tabel 12. Hasil Proyeksi Beban Puncak Skenario Kedua

\begin{tabular}{cccc}
\hline Tahun & $\begin{array}{c}\text { Beban } \\
\text { Puncak(MW) }\end{array}$ & Tahun & $\begin{array}{c}\text { Beban } \\
\text { Puncak(MW) }\end{array}$ \\
\hline 2015 & 47,5 & 2023 & 62,6 \\
2016 & 49,3 & 2024 & 63,6 \\
2017 & 51,2 & 2025 & 64,6 \\
2018 & 53,3 & 2026 & 65,6 \\
2019 & 55,6 & 2027 & 66,7 \\
2020 & 58,0 & 2028 & 67,7 \\
2021 & 60,5 & 2029 & 68,8 \\
2022 & 61,5 & 2030 & 69,8 \\
\hline
\end{tabular}

Hasil proyeksi beban puncak diperlukan sebagai acuan dalam menambah kapasitas trafo di gardu induk Kabupaten Purbalingga. Proyeksi beban puncak dihitung berdasarkan dari total konsumsi energi dan nilai load factor. Proyeksi beban puncak pada tahun 2030 untuk skenario satu sebesar 94,6 MW dan 69,8 MW pada skenario dua. Presentase peningkatan beban puncak dari tahun 2015 hingga tahun 2030 sebesar $99,46 \%$ pada skenario satu dan $47,2 \%$ pada skenario dua. Selesih pertumbuhan beban puncak antara skenario satu dengan dua sebesar $52,26 \%$.

Kapasitas trafo di gardu induk Kabupaten Purbalingga sebesar 30 MW. Kapsitas tersebut belum cukup untuk menyuplai energi listrik jika dilihat proyeksinya sampai pada tahun 2030 . Perlu adanya penambahan kapasitas trafo sebesar 90 MW atau 300\% dari kapasitas sebelumnya pada skenario satu atau melakukan penambahan $60 \mathrm{MW}$ atau $200 \%$ dari kapasitas sebelumnya jika skenario kedua diterapkan oleh pemerintah Kabupaten Purbalingga. Adanya penambahaan kapasitas trafo untuk menjamin kestabilan energi listrik di Kabupaten Purbalingga hingga tahun 2030

\section{SIMPULAN}

Hasil proyeksi pertumbuhan konsumsi energi listrik di Kabupaten Purbalingga menunjukkan adanya peningkatan dari 2015 hingga tahun 2030 dengan total konsumsi 
energi 295.548,7 MWh menjadi 645.892,6 MWh pada skenario satu dan menjadi 476.643,1 MWh pada skenario kedua. Peningkatan konsumsi energi dalam kurun waktu 15 tahun adalah $118 \%$ pada skenario satu dan $61,3 \%$ pada skenario kedua. Perbedaan pertumbuhan konsumsi energi listrik antara skenario satu dengan dua sebesar 56,7\%. Pertumbuhan konsumsi energi listrik dari tahun 2015 hingga tahun 2030 pada sektor pelanggan rumah tangga dari total konsumsi energi 210.124,5 MWh menjadi 296.015,6 MWh naik 40,8\% pada skenario satu sedangkan pada skenario kedua konsumsi energi menjadi 297.541 MWh naik 41,6\%. Pada sektor pelanggan bisnis total konsumsi dari 21.494 MWh menjadi 78.311,3 MWH naik 269\% pada skenario satu sedangkan pada skenario kedua konsumsi energi menjadi 43.129,3 MWh naik 100\%. Pada sektor pelanggan publik dari total konsumsi energi 19.195,1 MWh menjadi 62.219,4 MWh naik $224 \%$ sedangkan pada skenario kedua konsumsi energi menjadi 36.756,2 MWh naik 91\%. Pada sektor pelanggan industri dari total konsumsi energi 44.735 MWh menjadi 209.346,3 MWh naik $367 \%$ sedangkan pada skenario kedua konsumsi energi menjadi 99.216,6 MWh naik $122 \%$.

Presentase peningkatan beban puncak dari tahun 2015 hingga tahun 2030 dari 47,5 MW naik menjadi 94,6 MW atau naik 99,46\% pada skenario satu dan menjadi 69,8 MW atau naik sebesar $47,2 \%$ pada skenario kedua. Selisih pertumbuhan beban puncak antara skenario satu dengan skenario kedua sebesar 52,26\%.

Dengan kapasitas trafo sebesar $30 \mathrm{MW}$ di gardu induk Kabupaten Purbalingga maka perlu adanya penambahan kapasitas trafo sebesar 90 MW atau $300 \%$ dari kapasitas sebelumnya pada skenario satu atau melakukan penambahan 60 MW atau 200\% dari kapasitas sebelumnya jika skenario kedua diterapkan oleh pemerintah Kabupaten Purbalingga untuk menjamin kestabilan energi listrik di Kabupaten Purbalingga hingga tahun 2030.

\section{DAFTAR RUJUKAN}

Asri, R. 2017. Proyeksi Jangka Panjang Kebutuhan Energi Sulawesi Selatan Menggunakan Skenario Sistem Energi Bersih. Tesis. Universitas Gajah Mada Yogyakarta.

Badan Pusat Statistik Kabupaten Purbalingga. 2015. Kabupaten Purbalingga dalam Angka 2015. Diunduh pada tanggal $15 \mathrm{Mei}$ 2017 dari,

https://purbalinggakab.bps.go.id/website/p df_publikasi/Purbalingga-Dalam-Angka2015.pdf

Dewan Energi Nasional. 2015. Ketahanan Energi Nasional 2015. Diunduh pada tanggal 12 Juni 2017 dari, www.den.go.id/index.php/publikasi/downl oad/29

Djohar, A., \& Musaruddin, M. 2017. Analisis Kebutuhan dan Penyediaan Energi Listrik di Kabupaten Konawe Kepulauan Tahun 2017-2036 dengan Menggunakan Perangkat Lunak LEAP. Prosiding Seminar Nasional Teknik Elektro (FORTEI 2017).

Herbst, A., Toro, F., Reitze, F., \& Jochem, E. 2012. Introduction to energy systems modelling. Swiss Journal of Economics and Statistics, Vol 148(2), 111-135.

Hermawan, H., \& Karnoto, K. 2011. Proyeksi Kebutuhan dan Penyediaan Energi Listrik di Jawa Tengah Menggunakan Perangkat Lunak LEAP(Doctoral dissertation, University Diponegoro).

Insani, D. S., Badriana, B., \& Daud, M. 2019. Analisis Peramalan Kebutuhan Energi Listrik untuk Kabupaten Bireuen Menggunakan Perangkat Lunak LEAP. Jurnal Nasional Teknik Elektro, Vol 8(1), 32-41.

Kassa, D., Tuegeh, M., \& Pakiding, M. 2014. Ketersediaan Energi Listrik Sulawesi Utara Sampai Tahun 2020. Jurnal Teknik Elektro dan Komputer, Vol 4(1), 44-54.

Peraturan Menteri ESDM No. 24 Tahun 2015 tentang Pedoman Penyusunan Rencana Umum Ketenagalistrikan. Diunduh pada tanggal 12 Juni 2017 dari, 
http://jdih.den.go.id/download/1210/ped oman-penyusunan-rencanaumum-ketenagalistrikan

Prawaningtyas TD. 2009. Proyeksi dan Optimasi Pemanfaatan Energi Terbarukan. Tesis. Fakultas Teknik Universitas Indonesia.

Rajagukguk, A. S., Pakiding, M., \& Rumbayan, M. 2015. Kajian Perencanaan Kebutuhan dan Pemenuhan Energi Listrik di Kota Manado. Jurnal Teknik Elektro dan Komputer, Vol 4(3), 1-11.

Rencana Pembangunan Jangka Menengah Daerah (RPJMD) Kab. Purbalingga Tahun 2016-2021. Diunduh pada tanggal 10 Juni 2018 dari, https://bkppd.purbalinggakab.go.id/wpcontent/uploads/2018/05/RPJMD-20162021.pdf
Rencana Penyediaan Umum Tenaga Listrik (RUPTL) PT. PLN 2016 - 2025.

Diunduh pada tanggal 10 Juni 2017 dari, http://jdih.den.go.id/download/1210/ped oman-penyusunan-rencana-umumketenagalistrikan

Suhono. 2009. Kajian Perencanaan Permintaan dan Penyediaan Energi Listrik di Wilayah Kabupaten Sleman Menggunakan Perangkat Lunak LEAP. Skripsi. Universitas Gajah Mada Yogyakarta.

Winarno, O. T. 2006. LEAP (Long-range Energy Alternatives Planning System): Panduan Perencanaan Energi. CAREPI Project. 